ДОСЛІДЖЕННЯ МОДЕЛЕЙ ДЕРЖАВНОГО РЕГУЛЮВАННЯ У СФЕРІ ТУРИЗМУ

\title{
STUDY OF MODELS OF STATE REGULATION IN THE FIELD OF TOURISM
}

УДК 351.82: 379.85

DOI https://doi.org/10.32843/2663-52402019-11-14

\section{Леоненко Н.А.}

к. екон. наук,

науковий співробітник наукового відділу проблем державної безпеки

Навчально-науково-виробничий центр

Національний університет цивільного захисту України у статті проведено наукове дослідження моделей державного регулювання у ссрері туризму. Висвітлено основоположні фрактори, що обгрунтовують необхідність державного регулювання туризму, який на сучасному етапі здійснює не тільки локальний, але й глобальний вплив на соціально-економічні прочеси в державі. Узагальнено досвід закордонних країн стосовно пріоритетних напрямків діяльності в галузі туризму.

Ключові слова: державне регулювання, моделі державного регулювання туризму, сфрера туризму, туристична політика, організаційний процес державного регулювання туризму.

В статье проведено научное исследование моделей государственного регулирования в ссрере туризма. Освещены основополагающие фракторы, которые обосновывают необходимость государственного регулирования туризма, который на современном этапе осуществляет не только локальное, но и глобальное влияние на социально-экономические прочессы в государстве. Обобщен опыт зарубежных стран относительно приоритетных направлений деятельности в отрасли туризма.

Ключевые слова: государственное регулирование, модели государственного регули рования туризма, туристическая политика, организационный процесс государственного регулирования туризма.

The article deals with the research of models of state regulation in the field of tourism. The main factors, which justify the necessity of state regulation of tourism, which at the present stage is implementing not only local but also global influence on socio-economic processes in the state, are highlighted. The experience of foreign countries in relation to priority directions of activity in the field of tourism is generalized.

Key words: state regulation, models of state regulation of tourism, sphere of tourism, tourism policy, organizational process of state regulation of tourism.
Постановка проблеми у загальному вигляді. Дослідження та аналіз туристичної політики за кордоном викликає величезний інтерес для сучасного українського туризму, який в сучасних соціально-економічних умовах гостро потребує реструктуризації механізмів державного регулювання. Досвід різних країн показує, що успіх розвитку туризму безпосередньо залежить від того як на державному рівні сприймається ця галузь, наскільки вона забезпечується державною підтримкою. Потенціал туризму багатьом країнам світу дозволяє залучати значні кошти до державного бюджету, підвищувати доходи суміжних галузей економіки, сприяти зайнятості населення, покращувати стан туристичної інфраструктури.

у більшості країн багатогранний вплив туризму на економіку регулюється спеціально створеним центральним органом виконавчої влади. Однак рівень державного регулювання туристичною сферою неоднорідний в різних країнах світу та залежить від рівня їх економічного розвитку. Дана обставина $є$ причиною виникнення кількох основних моделей державного регулювання сферою туризму, на підставі дослідження яких можна простежити певні закономірності в організації туристичного бізнесу.

Аналіз останніх досліджень і публікацій. Аналізу закономірностей функціонування механізмів державного регулювання туристичної сфери приділяється значна увага в наукових працях як вітчизняних, так і закордонних вчених $[1 ; 2 ; 3 ; 4 ; 7]$. У роботах цих та інших авторів дослідження моделей державного регулювання в туризмі зазнали досить широкого та різнобічного дослідження на різних етапах соціально-економічного розвитку закордонних країн. Ідеї та положення, що присвячені обґрунтуванню, характеристиці та впорядкуванню наявних моделей державного регулювання туристичної сфери, послужили основою для даного дослідження.

Виділення невирішених раніше частин загальної проблеми. Проте, більш детальної уваги потребує аналіз досвіду державного регулювання в закордонних країнах з точки зору можливості його подальшої адаптації до вітчизняної практики організації, управління та регулювання туризму в Україні.

Метою статті $€$ дослідження та ґрунтовний аналіз наявних моделей державного регулювання у сфері туризму у світовому просторі в контексті нагальної необхідності удосконалення механізмів розвитку та функціонування туристичної сфери України.

Виклад основного матеріалу. В даний час спостерігається постійне та швидке зростання обсягу туристської діяльності, що призводить до того, що багатьма країнами туризм розглядається як один з важливих чинників розвитку держави. Безсумнівно, цей факт становить інтерес для структур, на державному рівні, що 
визначають напрямок розвитку та методи стимулювання найбільш перспективних галузей економіки.

Держава покликана відігравати чільну роль у розвитку галузей, визнаних пріоритетними для даної країни. Форми та межі такої участі кожна країна визначає самостійно з огляду на реальні можливості, загальні пріоритети та співвідношення попиту та пропозиції, що складається на внутрішньому ринку. Таким же чином вирішуються питання про співпрацю з приватним сектором: в яких областях його можна визнати найбільш значущим, та які форми воно повинно приймати для забезпечення максимальної ефективності.

Щодо економічних механізмів державного регулювання туристичної сфери, то зазвичай виходять з тих міркувань, що туризм як багатогалузевий комплекс потребує координації та регулювання, як жодна інша сфера. Водночас державна присутність і регламентація сковують підприємницьку ініціативу та заважають розвитку ринкових відносин. Іншими словами, держава повинна втручатися, коли цього вимагають інтереси суспільства та галузі, та відходити на другий план, дозволяючи суб'єктам туристичної діяльності діяти самостійно, якщо це необхідно, хоча поєднання суворої регламентації з розумною самостійністю представляється непростим завданням.

Необхідність державного регулювання туризму визначається такими чинниками:

1) комплексним характером галузі: елементами індустрії туризму є засоби розміщення, підприємства харчування, розважальні установи та туристські підприємства-організатори поїздок; крім того, туризм перебуває в тісній взаємодії з іншими галузями економіки - транспорту, торгівлі, сільського господарства, що вимагає зовнішнього координуючого втручання;

2) необхідністю збереження та раціонального використання чинників навколишнього середовища, культурної та природної спадщини у сфері туризму, підвищення престижу країни в очах міжнародної громадськості, розв'язання проблем безпеки та інше;

3) впливом туристської галузі на загальний стан економіки країни, що визначається крім інших чинників прямими грошовими надходженнями від внутрішнього та в'їзного туризму, а також активізацією діяльності в суміжних галузях, в тому числі завдяки мультиплікаційному ефекту;

4) великим виховним впливом туризму, особливо в межах своєї країни, формуванням почуття патріотизму; пропагандою національних туристських цінностей, яка є одним зі способів пропаганди державної моделі даної країни, в тому числі політичного ладу, економіки культури та способу життя населення.

Кожний з перерахованих чинників вже $є$ достатньою підставою для того, щоб держава звертала особливу увагу на туристську сферу. Крім того, низка обставин дозволяє віднести туристську галузь до галузей економіки, які здійснюють не локальний, а глобальний вплив на стан всієї економіки. Безумовно, державні органи не можуть не враховувати ці моменти під час визначення сфери першочергового регулювання.

Тобто, державне регулювання сфери туризму має здійснюватися у двох формах: по-перше, як поточний контроль, спрямований на реалізацію конкретних заходів з розвитку туризму; по-друге, як стратегічне регулювання, спрямоване на оцінку рівня досягнення поставлених цілей. Об'єктами стратегічного регулювання $є$ стан і ступінь використання туристського потенціалу країни, реалізація запланованих цільових програм, а також моніторинг зовнішнього та внутрішнього середовища та змін в економічній та соціальній політиці держави.

На сьогодні склалося декілька підходів до організаційного процесу державного регулювання туризмом у світі. Вивчаючи принципи державного регулювання туристичної діяльності, можна виділити кілька характерних позицій, присутніх на світовому туристичному ринку в даний час:

- жорстке авторитарне управління всіма аспектами туризму в країні;

- об'єднання сфери туризму з суміжними галузями господарства в рамках комбінованого міністерства;

- м'які підходи до регулювання та координації туристичної діяльності органами національної туристичної адміністрації;

- байдужість до туризму як до соціального та економічного явища [1].

Отже, зараз є наявними різні організаційні системи управління туризмом - від самостійних або суміжних міністерств до національних адміністрацій, безпосередньо підпорядкованих уряду. Крім того, деякі країни світу здійснюють регулювання туристичною діяльністю тільки на рівні регіональних органів державної влади, інші - не мають державних важелів впливу на сферу туризму взагалі.

Основні напрямки діяльності у сфері туризму з боку уряду різноманітних держав проілюстровано в табл. 1.

Підсумовуючи, з певною часткою умовності можна говорити про три моделі державного регулювання туризму. 


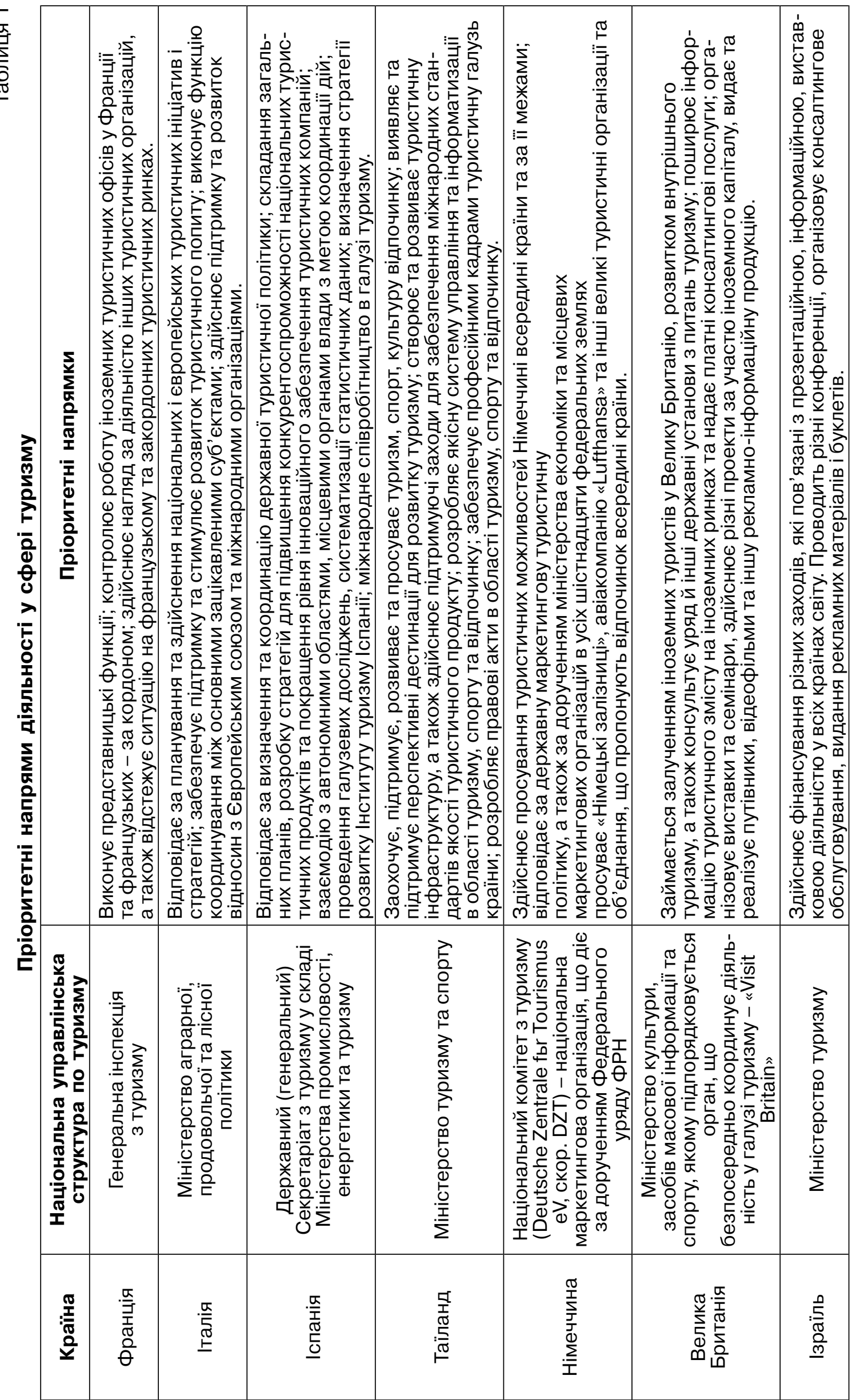




\begin{tabular}{|c|c|c|c|c|c|}
\hline 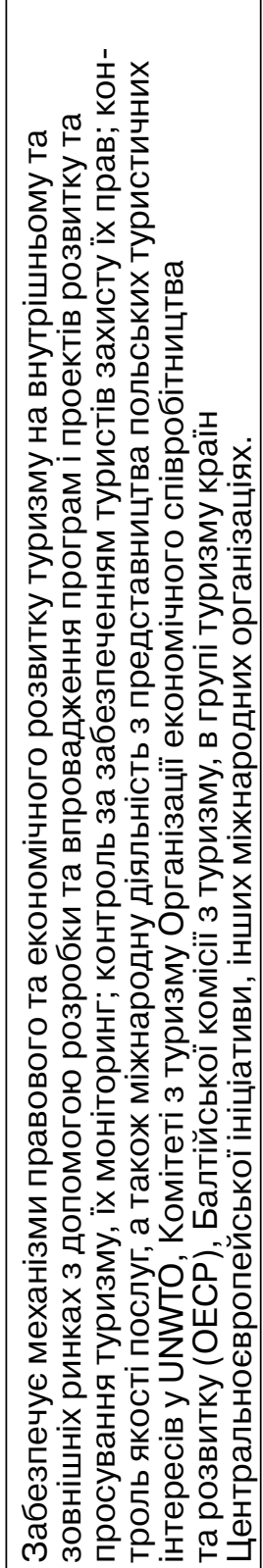 & 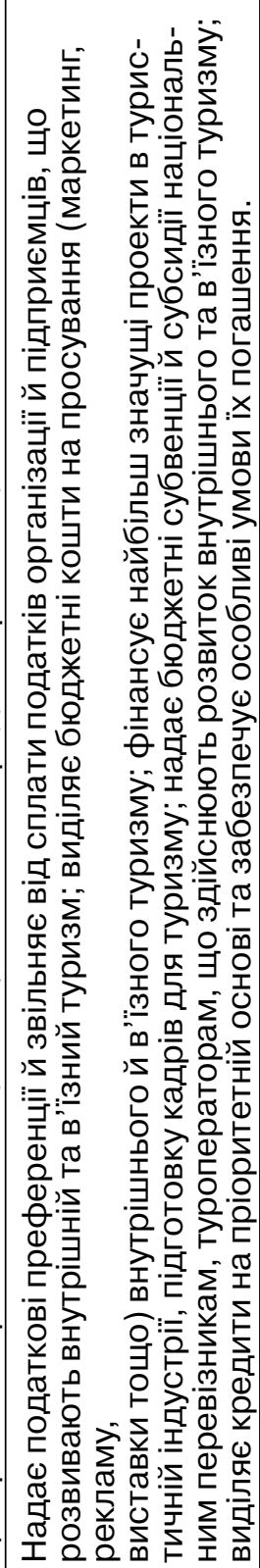 & 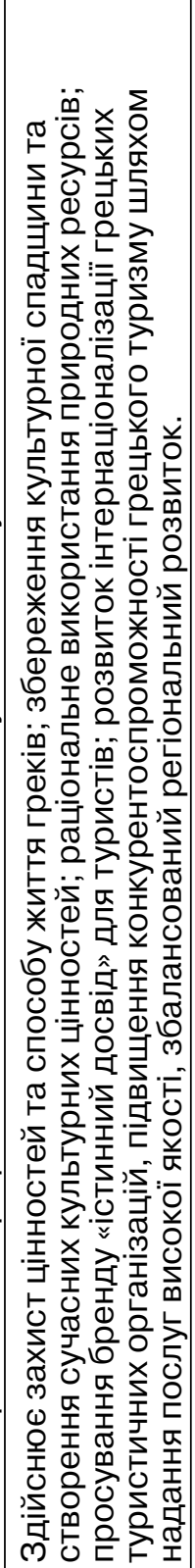 & 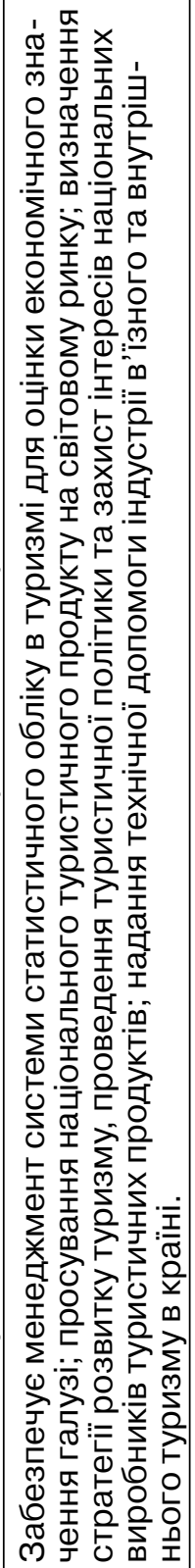 & 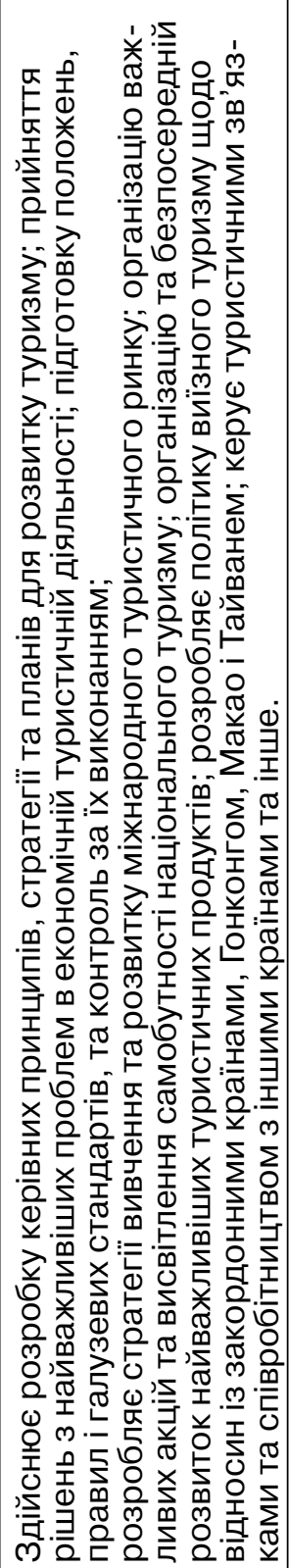 & 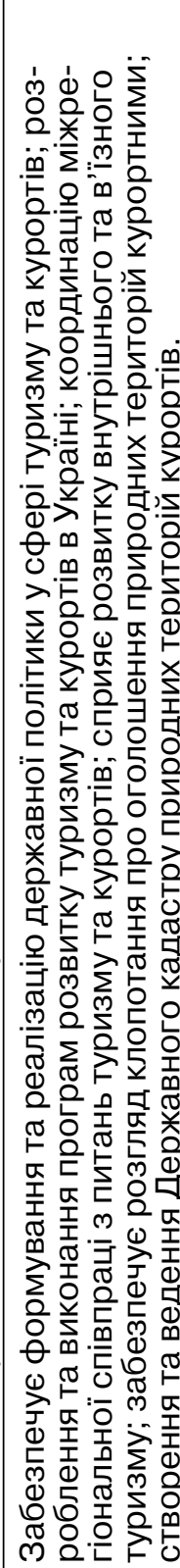 \\
\hline 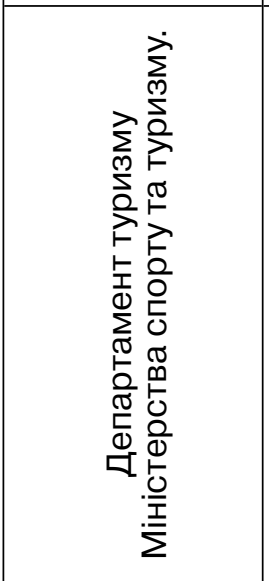 & 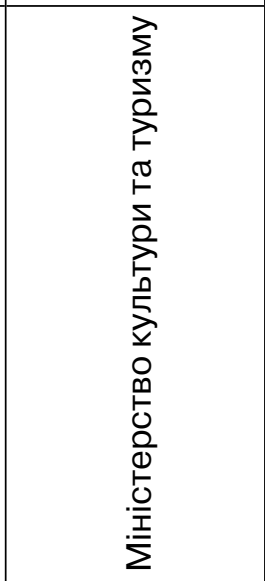 & 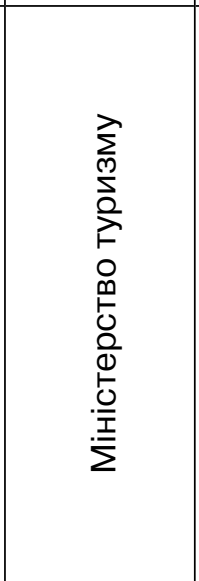 & 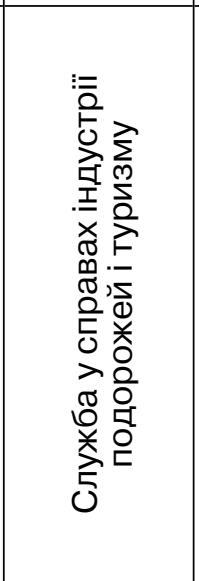 & 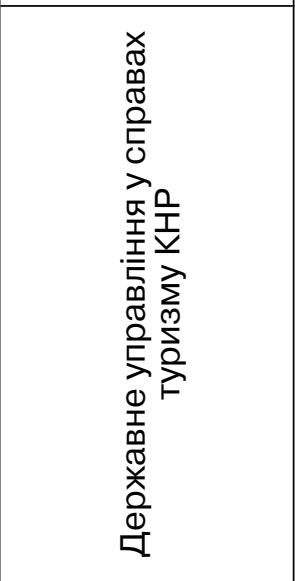 & 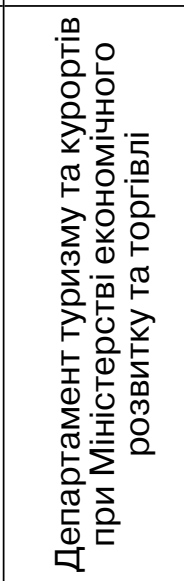 \\
\hline 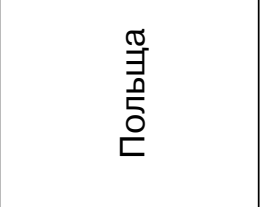 & 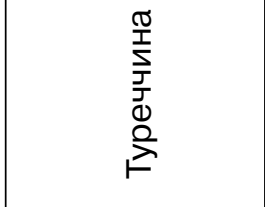 & ๕̊ & $\bar{u}$ & $\begin{array}{l}\stackrel{0}{\overrightarrow{5}} \\
\underline{n}\end{array}$ & $\stackrel{\Sigma}{\lambda}$ \\
\hline
\end{tabular}


Перша модель передбачає відсутність центральної державної туристичної адміністрації, всі питання вирішуються на місцях на основі принципів ринкової самоорганізації. Уряди окремих країн приймають управлінське рішення про відмову від національної туристської адміністрації в тих випадках, коли туризм країні взагалі не потрібен, коли країна займає міцне положення на міжнародному ринку туризму та $€$ привабливою для закордонних туристів або коли суб'єкти туристичного ринку свідомо займають сильні позиції, тобто здатні розв'язувати свої проблеми без державної участі.

Ця модель регулювання індустрії туризму використовується в США (у 1997 р. в США була ліквідована державна структура, що відала туризмом). Керівництво країни зважилося на це через низку причин:

- необхідність скорочення витрат федерального бюджету;

- наявність міцних позицій США на міжнародному ринку туризму;

- привабливість країни для закордонних туристів і впевненість в цій привабливості;

- існування сильних приватних компаній в індустрії туризму, які здатні на потужні самостійні рекламні акції в інтересах всього національного ринку туризму.

Ліквідація державної туристської адміністрації - дуже серйозний крок, для якого необхідні особливі умови.

Друга модель державного регулювання туризмом передбачає наявність сильного та авторитетного державного органу - міністерства, що концентрує у своїх руках контроль над діяльністю всієї галузі. Ця модель дуже ефективна, але для її реалізації потрібні певні умови, зокрема, значні фінансові вкладення коштів в індустрію туризму, рекламну та маркетингову діяльність, державне інвестування в туристичну інфраструктуру.

Так, єгипетська державна туристська адміністрація в 1999 р. тільки в Італії витратила на рекламу національного турпродукту приблизно 3 млн дол. США, що призвело до величезного ефекту та перевершило всі очікування.

Організація державного регулювання туріндустрії за цією моделлю поширена в Туреччині, Алжирі, Єгипті, Тунісі та інших не надто багатих країнах, в яких туризм є одним з основних джерел валютних надходжень.

Наприклад, в Туреччині Уряд в 1963 р. прийняв рішення про створення Міністерства туризму, під керівництвом якого почалося фінансування будівництва готелів, мотелів, клубів, з його допомогою були створені перші туристичні фірми. 31970 р. до повноважень міністерства туризму пов- ністю передано планування і будівництво туристських комплексів.

В Алжирі в 1963 р. створено Міністерство туризму. Офіційна структура національної туристичної індустрії була змінена в 1979 р. шляхом реорганізації національних корпорацій, зайнятих питаннями туристського розвитку, і створення державних підприємств. У 1976 р. утворено Національну туристську готельну корпорацію, на яку покладено відповідальність за управління та маркетинг всього туризму в державному секторі. Тоді ж було створено Алжирське національне управління туристських робіт, яке стало займатися всіма питаннями інфраструктури, і будівельних робіт, пов'язаних з розвитком туристичного сектора.

В Єгипті міністерство туризму, якому доручено керівництво розвитком і експлуатацією туристських районів, було утворено в 1973 р. У роботі міністерства беруть участь Генеральна компанія по туризму та готелям Єгипту. Для координації туристських планів була створена Вища рада по туризму, яка очолюється прем'єр-міністром країни.

Регулювання туристичною сферою Марокко також здійснюється спеціально створеним міністерством туризму, оскільки туризм $€$ стратегічним напрямом розвитку економіки країни. Туристська інфраструктура Марокко була створена до кінця 80-х рр. XX ст. У той час уряд заохочував елітний туризм для заможних клієнтів, але пізніше перейшло на заохочення масового сімейного туризму, і країна з допомогою цінової політики почала конкурувати навіть з Іспанією.

У Тунісі $€$ міністерство торгівлі, туризму та ремесел. У 1973 р. був прийнятий закон про формування туристських зон, який передав контроль за використанням землі на перспективних територіях державному агентству. Вжиті певні заходи для заохочення інвестицій в туристську галузь, зокрема, довгострокові податкові пільги та символічна плата за оренду землі, що забезпечило зростання фінансових вкладень в галузь, в тому числі іноземних інвестицій.

Третя модель державного регулювання туризмом переважає в розвинених європейських державах і полягає в тому, що питання розвитку туристичної діяльності країни вирішуються на рівні будь-якого багатогалузевого міністерства. Найчастіше, це міністерство економічного спрямування. Водночас підрозділ даного міністерства, в компетенції якого перебувають питання розвитку туризму, здійснює діяльність у двох напрямах: займається глобальними питаннями державного регулювання (розробкою нормативно-правової 
бази, координацією діяльності регіонів, міжнародним співробітництвом на міждержавному рівні, обробкою статистичної інформації) та маркетинговою діяльністю, участю у виставках, управлінням туристськими представництвами за кордоном.

Державна туристична адміністрація в розвинених європейських країнах працює у взаємодії з місцевою владою та приватним бізнесом для залучення до виконання державних завдань фінансових коштів 3 приватного сектора, знаходження взаємовигідних форм співпраці між органами управління різних рівнів. Наслідком реалізації цієї політики є виникнення змішаних за формою власності (державно-приватних) інститутів у сфері регулювання туристської діяльності.

Розглянемо, як приклад третьої моделі, державне регулювання туристичною індустрією в деяких країнах.

Основна організація Бельгії, що займається регулюванням туризму, Генеральний комісаріат з туризму, утворений в 1939 р. Він входить до складу Міністерства зв'язку. З 1977 р. підрозділи Генерального комісаріату було реструктуровано на три служби: центральна служба, яка в основному відповідає за організацію туризму за кордоном, і дві комісії по туризму (одна для громадян, які говорять по-французьки, інша - по-фламандськи), діяльність яких пов'язана з організацією туризму всередині країни, фінансовим втручанням держави, розвитком соціального туризму та співпрацею з компетентними міністерствами в питаннях планування та створення матеріальної бази туристських послуг. У провінціях створені туристські федерації та місцеві туристські управління при магістратах міст і центрах провінцій. Ці місцеві туристські федерації та туристські управління об'єднуються у Вищу раду по туризму та Вищу рада по соціальному туризму.

у Португалії Державний секретаріат з туризму входить до складу Міністерства економіки, інновацій та розвитку. у 1976 р. була створена Національна туристська корпорація, серед обов'язків якої - управління готелями та турагентствами, а також державними інвестиціями в туристський сектор економіки та торгівлі. У повноваженнях корпорації перебуває Національний інститут підготовки фахівців з туризму та готельної справи.

Функції регулювання в галузі туризму в Канаді покладені на Канадську комісію по туризму, яка включена в структуру промислового відділу Міністерства промисловості Канади. Основними завданнями Комісії $є$ : інформування клієнтів, розвиток туристичної індустрії світового класу, задоволення висхідних потреб туристів, зміцнення співпраці між різними туристичними організаціями та учасниками туристичної індустрії тощо.

В Еквадорі Національний директорат по туризму підпорядкований Міністерству промисловості, торгівлі та інтеграції. Він відповідає за питання планування, реклами та розвитку туризму, а також здійснює контроль цього розвитку. Формулювання генеральної політики Директорату перебуває у компетенції міністра промисловості, торгівлі та інтеграції, який очолює Міжміністерський комітет по туризму.

У Колумбії для розвитку туризму був створений Фонд розвитку туризму (Національний фонд туризму - «фонтури»), діяльність якого перебуває у веденні Міністерства торгівлі, промисловості та туризму. Основними напрямами діяльності Фонду $є$ розвиток внутрішнього туризму, здійснення різних соціальних програм, підтримка місцевих громад, просування національної культурної спадщини [7].

Така модель виборчої участі держави в регулюванні туристської індустрії властива більшості європейських країн, і вона найбільш прийнятна та близька для України. Так, за реалізацію туристичної політики відповідає Департамент туризму та курортів у складі Міністерства економічного розвитку і торгівлі України, до повноважень якого відносять: формування та реалізацію державної політики у сфері туризму та курортів; розроблення та виконання програм розвитку туризму та курортів в Україні; оформлення та видавання свідоцтва про встановлення об'єктам туристичної інфраструктури відповідної категорії; забезпечення створення та ведення реєстру свідоцтв про встановлення категорій об'єктам туристичної інфраструктури; забезпечення відповідно до законодавства ліцензування туроператорської діяльності; забезпечення ведення Ліцензійного реєстру суб'єктів туроператорської діяльності; забезпечення здійснення державного нагляду (контролю) за дотриманням суб'єктами господарювання вимог ліцензійних умов проведення туроператорської діяльності; бере участь у представлені країни в міжнародних туристичних організаціях і на міжнародних туристичних заходах; поширює інформацію про Україну та ї̈ туристичні можливості на міжнародному туристичному ринку [8].

Висновки. Отже, світова практика свідчить, що ідеальної формули, яка дала б можливість державі створити оптимальну структуру регулювання туристичної сфери, немає. Різні за формою системи державного регулю- 
вання індустрії туризму як способи реалізації туристської політики держави виконують в різних країнах схожі завдання, основними з яких $€$ регламентація туристської діяльності, інформаційне забезпечення, просування національного туристичного продукту, підготовка кадрів тощо. Туристична політика всіх названих країн, незалежно від обраної моделі державного регулювання, спрямована на зміцнення економіки туризму та підвищення економічної ефективності цієї галузі народногосподарського комплексу. I кінцевий позитивний результат такої політики більшою мірою залежить від ефективності управлінських рішень та зацікавленості влади в їх подальшій реалізації задля сталого розвитку туристичної сфери.

\section{ЛІТЕРАТУРА:}

1. Галасюк С.С. Научные исследования в сорере туризма : труды Международной туристской Академии. 2010. Вып.6. С. 189-204.
2. Артемова Е.И., Цаценко Н.А. Международный опыт управления в сорере продвижения и развития туризма. Научный журнал КубГАУ. Вип. 92 (08). 2013.

3. Ефрремова М.В., Смирнова И.П. Анализ зарубежного опыта государственных управленческих механизмов в сорере туризма. Экономический аналіз : теория и практика. № 5. 2003. С. 11-20.

4. URL: https://www.mincotur.gob.es/en-us/Paginas/ index.aspx.

5. URL: http://www.turismo.beniculturali.it/news/ turismo-decreto-di-trasferimento.

6. Особливості формування та реалізації туристичної політики держави: міжнародний, національний, регіональний досвід : монографрія / кол. авт., за ред. А.Ю. Парфріненка. Харків : ХНУ імені В.Н. Каразіна, 2013. 280 с.

7. Комарова Л.К. Менеджмент в социально-культурном сервисе и туризме : учеб. пособие для академического бакалавриата. Москва : Издательство Юрайт, 2018. 205 с.

8. URL: http://me.gov.ua/Documents/Detail?lang= uk-UA\&id=3e42d3b8-108a-4c21-a413-8d80aa724e5c\& title=ViddilRozvitkuTurizmu. 